\title{
A Case of Reconstruction of Surgical Defect after Removal of Intraosseous Hemangiomas on Nasal Dorsum
}

\author{
Yeon Hoo Kim, Sung Il Cho, Ji Eun Lee, and Ji Yun Choi \\ Department of Otorhinolaryngology-Head and Neck Surgery, School of Medicine, Chosun University, Gwangju, Korea
}

\author{
골내 혈관종 제거 후 발생한 비배부 결손 재건 1 예 \\ 김연후 · 조성일 · 이지은 · 최지윤 \\ 조선대학교 의학전문대학원 이비인후과학교실
}

\author{
Received January 17, 2015 \\ Revised May 12, 2015 \\ Accepted May 27, 2015 \\ Address for correspondence \\ Ji Yun Choi, MD, PhD \\ Department of Otorhinolaryngology- \\ Head and Neck Surgery, \\ School of Medicine, \\ Chosun University, \\ 365 Pilmun-daero, Dong-gu, \\ Gwangju 61453, Korea \\ Tel $+82-62-220-3200$ \\ Fax $+82-62-225-2702$ \\ E-mail happyent@naver.com
}

Intraosseous hemangioma arising from nasal bone is rare and has not been reported in the Korean literature. Hemangioma of the bone accounts for $0.7 \%$ of all bone tumors. The craniofacial region is a rare site of involvement, with mandible, zygoma, and maxilla being the most frequently affected areas. A 63 -year-old male patient presented with complaints of a protruding mass on the nasal dorsum that began 10 years ago. Computed tomography demonstrated a round mass with honeycomb appearance involving the nasal bone. An en bloc excision of the mass and nasal reconstruction was performed. Histopathological examination showed increased number of large cystically-dilated vessels with thin wall lying between thin trabeculae of lamellar bone in marrow space. During a one-year follow-up, the patient had no recurrence and cosmetic results were excellent. A case report of an intraosseous hemangioma arising on the nasal bone is described, together with a discussion of the relevant literature.

Korean J Otorhinolaryngol-Head Neck Surg 2016;59(2):145-9

Key Words Nasal bone - Primary intraosseous vascular malformation · Rhinoplasty.

\section{서 론}

골내 혈관종(intraosseous hemangioma)은 골성 구조에서 기원하여 혈관성 구조로 증식하는 종양으로 그 원인은 알려 져 있지 않으며, 외상과 관련이 있다는 보고가 있다.1) 혈관증식 이 풍부한 양성종양으로 과오종(hamartoma) 또는 혈관기형 으로 불리기도 한다. ${ }^{2)}$ 모든 골성 종양의 $0.7 \%$ 를 차지하며, 주 로 척추와 두개에 발생하지만 두개안면골에서는 매우 드문 것 으로 되어 있다. ${ }^{3)}$ 안면골에서는 하악골, 협골, 상악골, 전두골 과 비강 내 발생이 보고되고 있다. 특히 비골에 발생한 골내 혈관종은 매우 드물며 국내에 아직 보고된 바가 없다.,5) 이 질 환은 1845 년 Toynbee ${ }^{6}$ 에 의해 처음 기술된 드문 양성종양으 로 조직학적으로 진단이 되므로 숙련된 병리의사가 아니면 다른 골성 종양과 감별이 쉽지 않다. 하지만 영상학적인 특징 들을 숙지하고 있다면 이 질환에 대한 진단을 내리는 데 도움
이 된다. 저자들은 비배부에 발생한 골내 혈관종을 체험하였 기에 문헌고찰과 함께 보고하고자 한다.

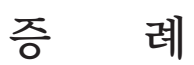

63세 남자 환자가 약 10 여 년 전부터 서서히 증가하는 비배 부의 무통성의 종괴와 그에 따른 외비변형을 주소로 내원하 였다. 종물 외에 다른 코와 관련된 증상은 호소하지 않았다. 외형상 비배부에 돌출한 약 $3 \mathrm{~cm}$ 가량의 불규칙한 경계를 가 지는 단단한 종괴 소견을 보였으며, 비내시경상 특이소견은 보이지 않았다(Figs. 1 and 2). 환자는 내원 12년 전 동일 부위 의 종괴로 비강 내 접근을 통한 절제술을 시행한 과거력이 있었으나 조직검사 결과는 기억하지 못했다. 외래 내원 후 시 행한 부비동 전산화단층촬영상 비골을 중심으로 하여 벌집 모양의 주변부와 경계가 분명한 조영 증강된 약 $3 \times 2 \mathrm{~cm}$ 크기 

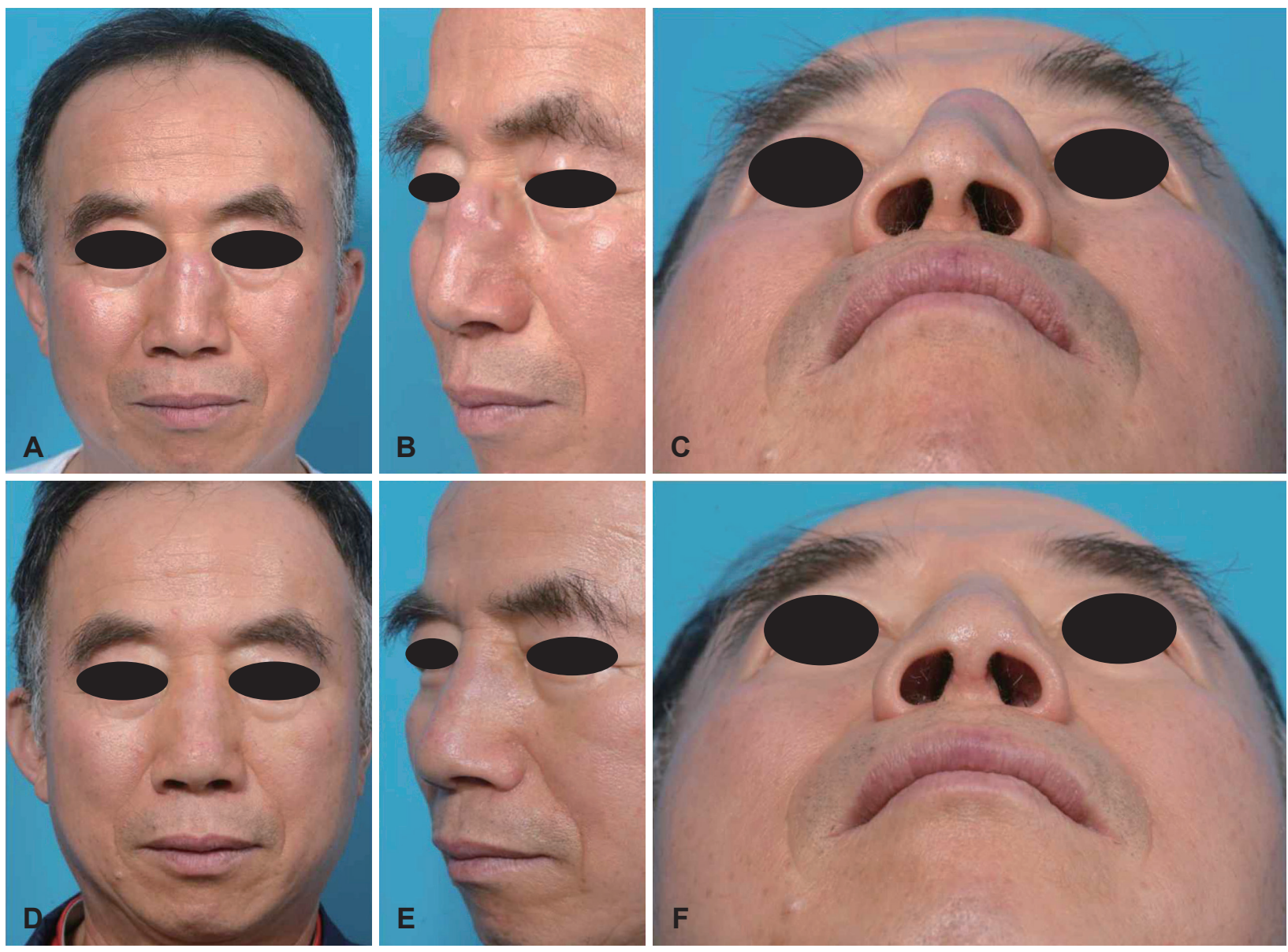

Fig. 1. Pre- (above) and post-operative (below) facial photos. Preoperative photography shows protruding and irregular round mass on the nasal dorsum ( $A, B$, and $C$ ) and postoperative photography shows well-reconstructed nasal dorsum (D, E, and F).
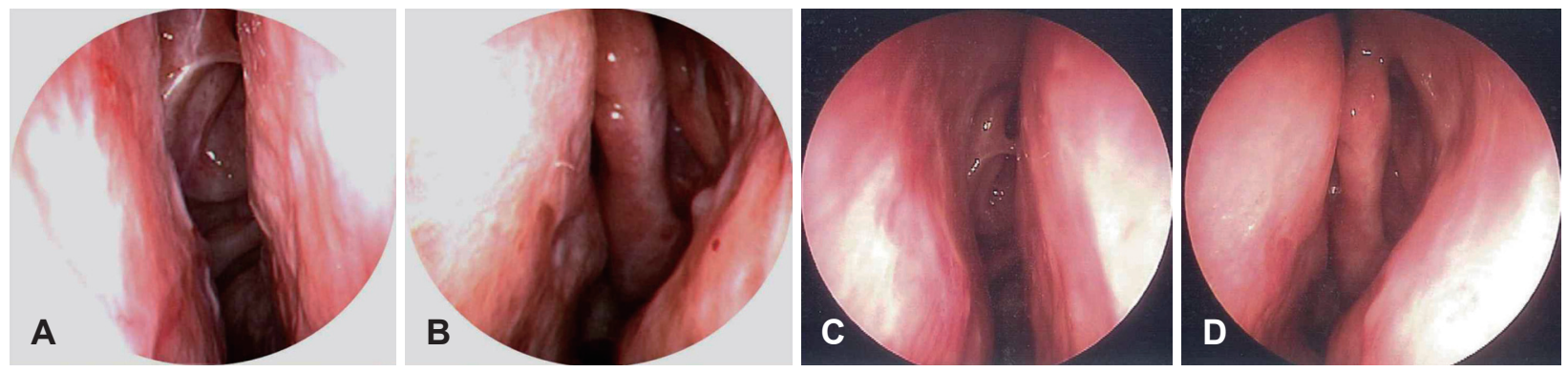

Fig. 2. Pre- and post-operative nasal cavity photos. Preoperative endoscopic view show no visible mass in the nasal cavity (A and B). Postoperative endoscopic view show no interval changes (C and D).

의 종괴가 관찰되었다(Fig. 3). 이전 수술의 조직검사 결과와 영상학적 소견을 고려하여 골종으로 판단하였으며, 전신마취 하에 종괴 절제술 및 절제 후 결손이 우려되는 비삼각의 재건 을 계획하였다.

전신마취 하에 통상적인 비성형 외비접근법으로 수술을 진 행하였으며, 비배부의 종괴를 노출시킨 후 절골도와 메스, 드 릴을 이용하여 종괴를 포함하여 비골, 비중격의 상부(사골의 수직판), 상비익연골의 일부를 절제하였다. 결손부위를 재건
하기 위해서 알루미늄 포일로 결손부위의 크기를 잰 후 이식 물의 노출을 막고 이식물의 지지를 위해 우측 귀에서 얻은 귓 바퀴연골과 피부를 포함한 복합조직이식과 비중격 연골을 이 용하여 비배부의 안쪽 부분을 재건하고, 비근부를 덮어주었 다. 함몰된 부위는 Gore-tex sheet를 여러 겹으로 디자인하여 함몰된 부위를 채워주었다. 우측 귀의 공여부는 결손부위가 커 일차봉합이 불가능한 상태로 좌측 귀의 후방에서 피부 이 식물을 체취하여 우측 귀의 결손부위를 메꿔주었다. 마지막 

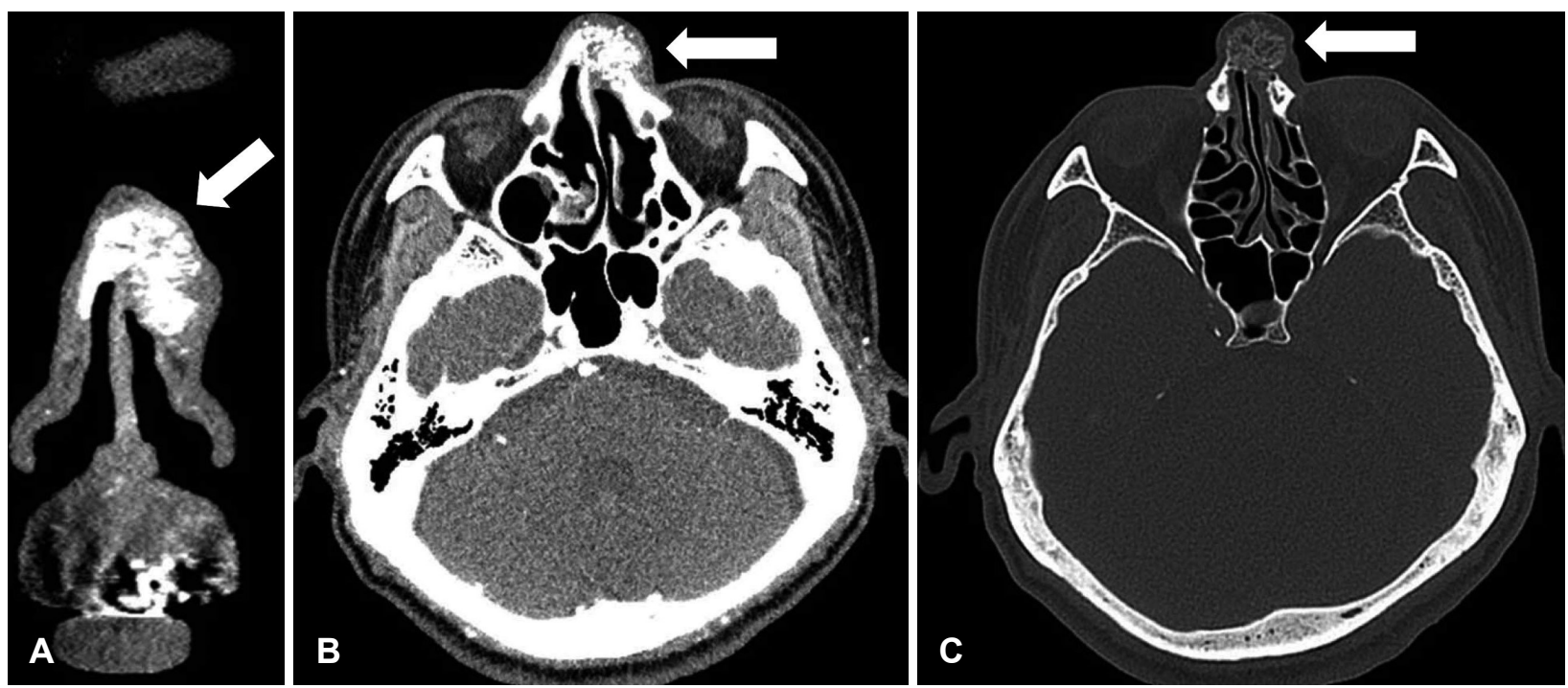

Fig. 3. Pre-operative computed tomography images. Preoperative coronal (enhanced view) (A). Preoperative axial (enhanced view) CT scan demonstrated $2.5 \times 2 \mathrm{~cm}$ sized round lesion (white arrow) arising from the nasal bone. Honeycomb-shaped high bony density lesion on the nasal dorsum can be observed (B and $C)$.
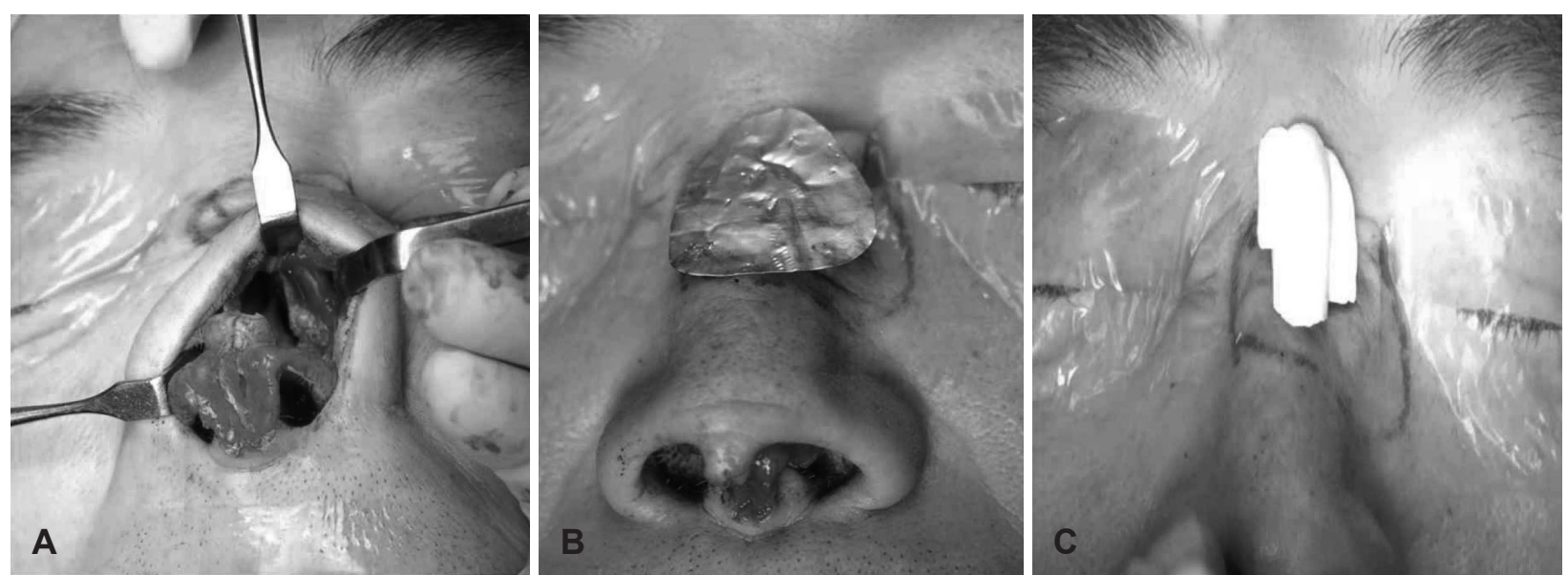

Fig. 4. Intraoperative photos. Bone and cartilage defect can be observed (A). Check the defect size using aluminum foil (B). Dorsal augmentation using Gore-tex (C).

으로 좌측 귀는 일차봉합을 시행하였다. 제거된 종괴는 $3 \times 2$ $\mathrm{cm}$ 크기로 단단한 골성 양상의 불규칙한 종괴였고 내부에 벌집 모양의 공간이 존재하였다. 수술 중 심한 출혈 소견은 보 이지 않았다(Fig. 4).

병리조직학적 검사상 정상적인 골소주(trabeculae) 및 내피 세포들로 둘러싸여 있는 혈관 통로들이 존재하고 있었고, 최 종 조직학적 진단은 골내 혈관종으로 확인되었다(Fig. 5). 수 술 시행 2일째 비강 내 패킹을 제거하였으며 5일째 퇴원하여 외래에서 봉합사를 제거하였다. 수술 후 1 년이 지난 현재까 지 외래 관찰 중이며 특별한 합병증 및 재발의 소견은 보이 지 않고 있다.

\section{고 찰}

일반적으로 혈관종이 어릴 때 발생하는 반면 골내 혈관종 은 40 50대에 주로 발생한다. ${ }^{7.8)}$ 대부분의 혈관종이 연조직에 서 기인한 반면 혈관기형(vascular malformation)은 골성 구조 를 침범할 수 있기 때문에 몇몇 저자는 골내 혈관종을 혈관 기형 또는 과오종(hamartomas)으로 분류하도록 제안하기도 하였다. ${ }^{4)}$ 남자에 비해 여자에게서 3 배 정도 많이 발생하며, 고 립된 병변으로 좌측에 더 흔하게 발생한다.9) 조직학적으로 골내 혈관종은 내부의 혈관망에 따라 정맥(venous)형, 해면체 (cavernous)형, 모세혈관(capillary)형으로 나뉘는데, 해면체 형은 가장 흔한 형태로 주로 두개골에 발생하며 ${ }^{10,11)}$ 본 증례 의 경우 해면체형이었다. 비강이나 비골에서 발생한 골내 혈관 

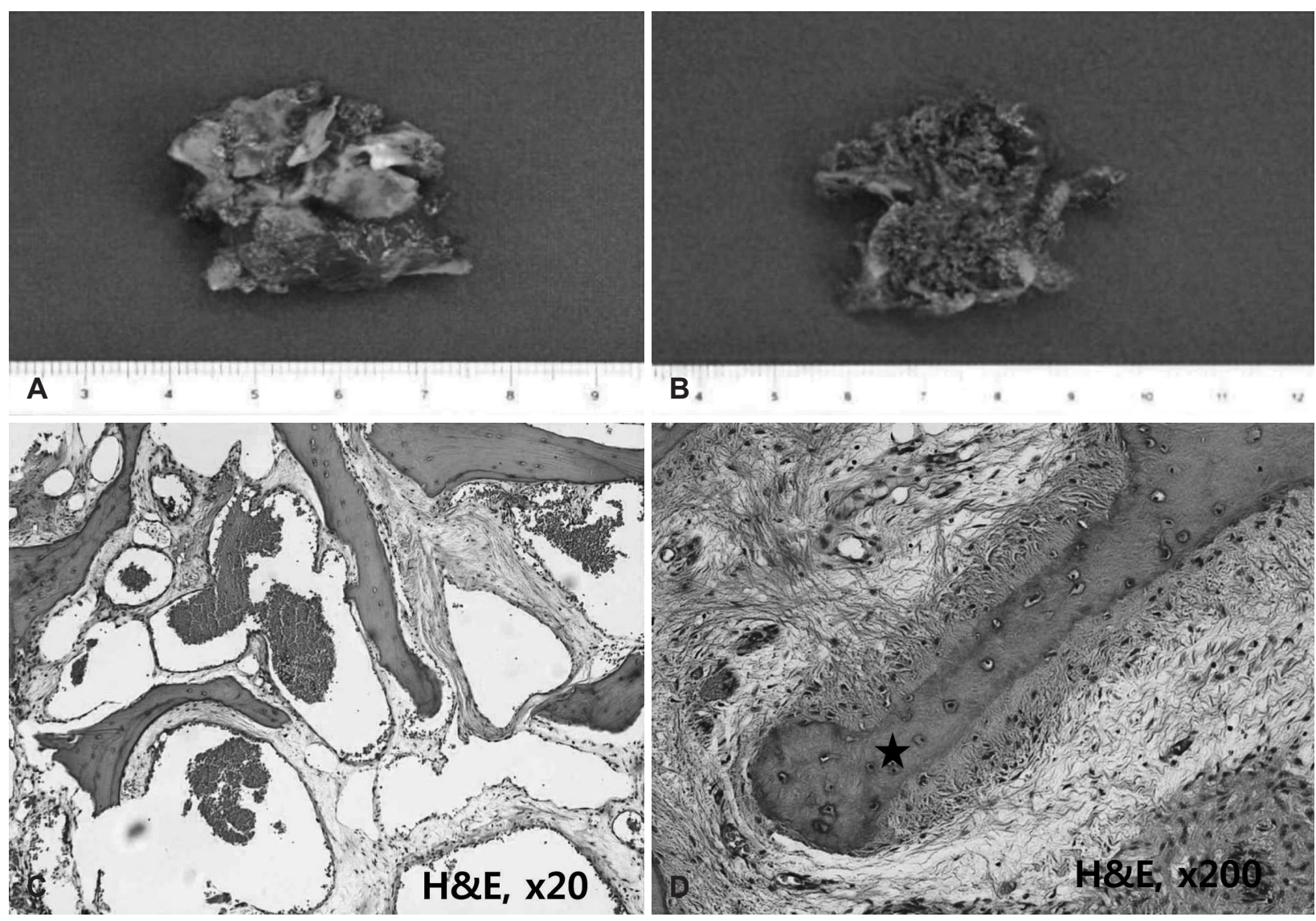

Fig. 5. Gross and microscopic histopathologic appearances of the surgical specimen. A $3.5 \times 3 \mathrm{~cm}$ sized dark- reddish bony mass with honeycomb appearance can be observed $(A$ and $B)$. There are increased number of large cystically dilated vessels with thin wall lying between thin trabeculae of lamellar bone are recognized in marrow space (H\&E stain, $\times 20)(C)$. In mid power field, areas of reactive new bone formation (black star) are recognized (H\&E stain, $\times 200)(D)$.

종은 현재까지 국외 문헌에서 9증례 보고가 되어 있다. ${ }^{12-14)}$ 저 자들은 본 증례의 종괴가 부드럽고 경계가 불분명하고 압박 시 창백해지는 보라색 병변을 보이는 해면상 혈관종의 특징 보다는 비교적 단단하고, 압박 시 잘 눌러지지 않으며, CT 상 골내 혈관종에 합당한 내부 거품 모양과 부분적 골용해 소견 을 보였기에, 초기 병리 진단 결과 해면상 혈관종으로 나왔으 나 병리과에 재심의를 의뢰하여 정확한 진단을 도출하였다.

골내 혈관종을 진단하기 위한 영상학적 검사는 전산화단 층촬영(computed tomography, CT)이나 자기공명영상검사 (magnetic resonance imaging, MRI)가 이용되며, 특히 CT 는 bone window에서 종양의 위치와 범위 등을 더 잘 보여주 므로 수술을 계획하고 진단하는 데 더 유용하다. MRI는 주변 조직으로의 침범된 범위를 확인하는 데 도움이 된다. 이 질환 의 특징적인 CT 소견으로는 내부에 벌집 모양, 비누거품 모양 의 음영을 보이고 부분적인 골미란과 방사 형태의 태양광선 모양의(sun burst appearance) 음영을 보인다. ${ }^{6,7)}$ 특히 이러한 방사형태의 골소주는 두개골이나 협골 등에서 발생하는 골 내 혈관종에서 특징적이다. 본 증례에서도 종괴 내부에 벌집
또는 비누거품 모양의 골 용해 부위가 관찰되었으나 방사형 태의 골 소주는 뚜렷하지 않았다(Fig. 2). T1 강조 자기공명영 상에서 골내 혈관종은 비균질의 신호강도를 보이고, 병변의 지방함유 정도나 혈액의 저류에 따라 고신호 강도부터 저신 호 강도까지 다양하게 나타난다. T2 강조 자기공명영상에서 골내 혈관종은 고신호 강도를 보인다. 본 증례에서는 CT상 의 특징적인 소견으로 골내 혈관종을 의심할 수 있는 상황이 어서 MRI를 추가로 촬영하지 않았다.

수술 중 출혈을 최소화하고 좋은 수술 시야를 확보하기 위 해 수술 전 혈관조영술 및 색전술이 시행될 수 있으나 아직까 지 논란의 여지가 있다. 크기가 큰 종괴일 경우 혈관조영술 및 색전술을 술 전에 시행할 수 있으나, 작은 종양일 경우에는 혈 관의 발달이 미약하거나 거의 확인할 수 없을 정도인 경우도 있기 때문에 반드시 시행할 필요는 없어 보인다. 색전술을 계 획한다면 적어도 수술이 시행되기 48시간 이내에 시행해야 종 양으로의 곁순환을 막을 수 있다. 외래에서 시행하는 절제 생검은 다량 출혈의 위험성이 있으므로 조심해야 한다. 본 증 례에서는 수술 전 전산화단층촬영상 약간의 조영 증강만 관 
찰되어 색전술을 계획하지는 않았고, 실제 수술 중에도 출혈 양이 많지 않았다.

치료는 병변의 완전 절제이지만 해부학적으로 완전한 제거 가 힘든 경우에는 잔존하는 병변에 방사선 치료를 할 수 있 다. ${ }^{3)}$ 그러나 방사선 치료는 조직괴사, 뼈 혹은 치아의 발달장 애, 방사선에 의한 육종, 방사선 치료에 의한 혈관종 등의 합 병증이 발생할 수 있으므로 신중히 고려되어야 한다. 다른 치료방법으로는 경화요법(sclerotherapy)과 색전술(embolization)이 고식적인(palliative) 치료로서 고려될 수 있다. ${ }^{4}$ 현재 까지 보고된 증례 및 우리의 증례에서는 재발의 증거는 없었 으나, 추적관찰의 기간이 짧아 이 질환의 정확한 예후를 알기 는 어렵다.

대부분 종양의 절제 및 결손부위의 재건술이 시행되며 종 양을 제거한 뒤 발생한 비교적 작은 수술부위의 결손은 유경 피판 또는 피부이식을 통해 재건할 수 있고, 큰 결손의 경우 안면골, 늑골 또는 합성물질을 이용한 재건이 필요하다. ${ }^{14}$

Zins 등 ${ }^{14}$ 은 비골에 발생한 골내 혈관종을 외비 피부에 직 접 절개를 가하여 종괴를 절제 후 두개골을 이용하여 콧등 의 재건을 시행하였고, $\mathrm{Yu}$ 등 ${ }^{15)}$ 은 외비접근법을 통해 종괴를 절제 후 비중격 연골을 이용하여 결손부를 재건하였다고 보 고하였다. 이들 모두 재발이나 합병증 없이 좋은 결과를 보였 다. 본 증례는 콧등에 발생한 종괴로 인한 미용적 불만족을 주소로 내원한 환자로 외비접근법을 이용하여 종괴를 절제 후 동시에 미용적 재건술을 시행하였다. 종괴를 절제 후 비골 이 거의 남아 있지 않고 결손부위가 넓었으며 비강 내로 연결 되어 있어 비강 내 점막부와 비골 및 연골부의 재건이 필요 하였다. 비강 내 점막부, 비골 및 연골부의 재건을 위해 귀의 후방에서 연골과 피부를 포함한 복합조직이식편을 채취하여 결손부를 재건하고, 미용적 개선을 위하여 고어텍스를 이용한 융비술을 시행하였으며, 수술 후 만족할 만한 결과를 얻었다.

본 증례에서처럼 서서히 자라는 팽창성 골성 종괴가 비배 부에 관찰되었을 때 감별해야 할 질환으로는 골종(osteoma), 섬유형성 이상증(fibrous dysplasia), 골화성 섬유종(ossifying fibroma), 수막종(meningioma), 유피낭종(dermoid tumor), 다 발성골수종(multiple myeloma), 조직단핵구증(Langerhans cell histocytosis) 등이 있다. 전형적인 영상학적 특징들이 이 러한 종양들을 감별하는 데 도움을 주며, 수술 후 현미조직검 사상 정상적인 골소주(trabeculae) 및 내피세포들로 둘러싸
여 있는 혈관 내강이 보이면 감별 진단에 도움이 된다.

요약하면, 비배부에 발생한 골내 혈관종은 매우 드물며 CT 소견이 진단에 도움이 되지만 정확한 진단은 조직검사를 시행 하여야 한다. 완벽한 수술적 절제가 가장 효과적인 치료로서 본 증례에서는 외비 성형술 접근법으로 종양을 노출시킨 후 완전절제가 가능하였고, 안면의 종양의 제거 후 비배부의 미 용적 재건이 필요하였다. 술 후 재발소견 없이 미용적으로 좋 은 결과를 보이고 있어 문헌고찰과 함께 보고하는 바이다.

\section{REFERENCES}

1) Marshak G. Hemangioma of the zygomatic bone. Arch Otolaryngol 1980;106(9):581-2.

2) Koybasi S, Saydam L, Kutluay L. Intraosseous hemangioma of the zygoma. Am J Otolaryngol 2003;24(3):194-7.

3) Peterson DL, Murk SE, Story JL. Multifocal cavernous hemangioma of the skull: report of a case and review of the literature. Neurosurgery 1992;30(5):778-81; discussion 782.

4) Moore SL, Chun JK, Mitre SA, Som PM. Intraosseous hemangioma of the zygoma: CT and MR findings. AJNR Am J Neuroradiol 2001; 22(7):1383-5.

5) Fahmy FF, Back G, Smith CE, Hosni A. Osseous haemangioma of inferior turbinate. J Laryngol Otol 2001;115(5):417-8.

6) Toynbee J. An account of two vascular tumours developed in the substance of bone. Lancet 1845;2:676.

7) Sherman RS, Wilner $D$. The roentgen diagnosis of hemangioma of bone. Am J Roentgenol Radium Ther Nucl Med 1961;86:1146-59.

8) Valentini V, Nicolai G, Lorè B, Aboh IV. Intraosseous hemangiomas. J Craniofac Surg 2008;19(6):1459-64.

9) Sargent EN, Reilly EB, Posnikoff J. Primary hemangioma of the skull. Case report of an unusual tumor. Am J Roentgenol Radium Ther Nucl Med 1965;95(4):874-9.

10) Adler CP, Wold L. Haemangioma and related lesions. In: Fletcher CDM, Unni KK, Mertens F, editors. World Health Organization classification of tumours: pathology and genetics of tumours of soft tissue and bone. Lyon: IARC Press;2002. p.320-1.

11) Suss RA, Kumar AJ, Dorfman HD, Miller NR, Rosenbaum AE. Capillary hemangioma of the sphenoid bone. Skeletal Radiol 1984; 11(2):102-7.

12) Bridger MW. Haemangioma of the nasal bones. J Laryngol Otol 1976;90(2):191-200.

13) Neivert H, Bilchick EB. Primary hemangioma of the nasal bone. Arch Otolaryngol 1936;24(4):495-501.

14) Zins JE, Türegün MC, Hosn W, Bauer TW. Reconstruction of intraosseous hemangiomas of the midface using split calvarial bone grafts. Plast Reconstr Surg 2006;117(3):948-53; discussion 954.

15) Yu MS, Kim HC, Jang YJ. Removal of a nasal bone intraosseous venous malformation and primary reconstruction of the surgical defect using open rhinoplasty. Int J Oral Maxillofac Surg 2010;39 (4):394-6. 